\title{
Vrednotenje zahtevnejših geografskih učnih vsebin na vseh ravneh izobraževanja
}

\author{
Tatjana Resnik Planinc \\ Dr., Oddelek za geografijo, Filozofska fakulteta, Univerza v Ljubljani, \\ Aškerčeva 2, 1000 Ljubljana, Slovenija \\ e-mail: davor.planinc@siol.net
}

\section{Izvleček}

$\checkmark$ geografskem izobraževanju se srečujemo $z$ didaktičnim problemom prenosa in razumevanja zahtevnejših geografskih učnih vsebin, ki naj bi bile s stališča stroke vključene v celotno vertikalo geografskega izobraževanja. Nadaljnje izboljševanje pouka in študija geografije ter zagotavljanje kakovostnih učnih načrtov za učence na vseh stopnjah geografskega izobraževanja zahteva definiranje zahtevnejših geografskih učnih in študijskih vsebin, definiranje vzrokov za njihovo pojavljanje, utemeljitev razlogov za njihovo vključitev $v$ učne načrte ter ugotavljanje poti in metod za njihovo razumevanje in usvajanje.

Ključne besede: geografija, zahtevnejše geografske učne vsebine, geografsko izobraževanje, izobraževalni problem

\section{Evaluation of more Demanding Geographical Contents Regarding all Educational Levels}

\begin{abstract}
The article deals with a didactical problem of transfer and understanding of more demanding geographical contents which are included into geographical educational vertical. Further improvement of geography teaching and assurance of high quality syllabus on every level of geographical education require a defining of more demanding geographical contents and reasons for their difficulty, argumentation of their incorporation into syllabuses and assessment of ways and methods for dealing with them and for their adoption. The analyses of scientifically demanding geographical contents offer the origins for better organisation of contents in the vertical of geographical education and the origins for better education of future geography teachers.
\end{abstract}

Key words: geography, more demanding geographical contents, geographical education, educational problem. 


\section{UVOD}

V geografskem izobraževanju se srečujemo z didaktičnim problemom prenosa in razumevanja zahtevnejših geografskih učnih vsebin, ki naj bi bile s stališča stroke vključene $\mathrm{v}$ osnovnošolske in srednješolske učne načrte ter $\mathrm{v}$ študijski program. $\mathrm{Z}$ raziskavami med učenci in učitelji geografije osnovnih in srednjih šol v Sloveniji, študenti geografije in univerzitetnimi pedagoškimi delavci na oddelkih za geografijo na Filozofski fakulteti v Ljubljani in Pedagoški fakulteti v Mariboru ter svetovalci za geografijo na Zavodu RS za šolstvo smo zato želeli:

- primerjati obstoječo vertikalo geografskega izobraževanja s psihofizičnimi sposobnostmi otrok in mladostnikov ter njihovimi potrebami,

- definirati zahtevnejše geografske vsebine v osnovni šoli (6., 7., 8. razred), $\mathrm{v}$ srednji šoli (splošna gimnazija, strokovna gimnazija, srednje tehnične in poklicne šole) ter v visokošolskem študiju geografije (Filozofska fakulteta v Ljubljani, Pedagoška fakulteta v Mariboru),

- ugotoviti za koga so lahko učne vsebine zahtevnejše - ali za učitelje (poučevanje) ali za učence (učenje),

- ugotoviti vzroke zahtevnosti določenih geografskih učnih vsebin,

- proučiti pomen in vpliv ponavljanja, utrjevanja in preverjanja znanja pri usvajanju zahtevnejših geografskih učnih vsebin,

- ugotoviti stopnjo medpredmetnega sodelovanja $\mathrm{v}$ osnovnih in srednjih šolah.

\section{REZULTATI RAZISKOVALNEGA DELA}

V raziskavah je sodelovalo 265 učiteljev geografije na osnovnih in srednjih šolah R Slovenije v šolskem letu 1999/00, 1612 učencev in dijakov osnovnih in srednjih šol R Slovenije v šolskem letu 1999/00, 215 študentov geografije ter absolventov geografije na oddelkih za geografijo Filozofske fakultete v Ljubljani in Pedagoške fakultete v Mariboru v študijskem letu 1999/00 ter 20 univerzitetnih pedagoških delavcev na oddelkih za geografijo Filozofske fakultete v Ljubljani in Pedagoške fakultete v Mariboru v študijskem letu 1999/00.

$\mathrm{V}$ intervjujih je sodelovalo 12 učiteljev osnovnih in srednjih šol R Slovenije v šolskem letu 1999/00 ter trije pedagoški svetovalci za geografijo, zaposleni na Zavodu za šolstvo R Slovenije v letu 2000.

\subsection{Prvi del raziskovalnega dela}

Glavni namen prvega dela raziskave je bil definiranje zahtevnejših geografskih pojmov oziroma gesel v OŠ in na različnih vrstah SS̆. 
Vprašalnik za učitelje je vseboval 8 vprašanj. Na tem mestu se bomo osredotočili predvsem na zadnje vprašanje, $v$ katerem so bili v skladu z veljavnimi učnimi načrti v sklopu posameznih učnih vsebin našteti vsi pojmi oziroma gesla, katerih usvojitev predvideva učni načrt. Učitelji so morali pri vsaki posamezni učni vsebini definirati tiste pojme oziroma gesla, za katera menijo, da so za njihove učence zahtevnejši in težje razumljivi od ostalih.

Vsi učenci so dobili vprašalnik z 12 vprašanji. Medtem ko se vprašanja od številke 1 do številke11 niso razlikovala glede na razred in glede na vrsto šole, pa se je 12 vprašanje nanašalo na učno snov predhodnega razreda, ki so ga obiskovali učenci. Učenci so bili izbrani naključno, ne glede na spol, učni uspeh ali oceno pri geografiji. Tako kot pri učiteljih se je tudi pri učencih zadnje vprašanje nanašalo na zahtevnost geografskih učnih vsebin. Učenci so odgovarjali za predhodni razred.

Tabele prikazujejo primerjavo izbora tistih pojmov oziroma gesel, ki jih je več kot $60 \%$ učiteljev oziroma učencev v posameznih razredih osnovne šole in različnih vrst srednjih šol definiralo kot zahtevnejše oziroma težje razumljive.

Tabela 1: OSNOVNA ŠOLA - 6. razred: skupno 98 pojmov oz. gesel.

\begin{tabular}{|l|c|c|}
\hline UČITELJI & UČENCI \\
\hline POJEM & 71,4 & $/$ \\
\hline $\begin{array}{l}\text { svoboden pretok ljudi, blaga, delovne } \\
\text { sile }\end{array}$ & 70,3 & \\
\hline vpadni kot sončnih žarkov & 61,5 & \\
\hline svetlobno leto & 61,5 & \\
\hline poletni in zimski sončni obrat & 61,5 & \\
\hline geografska lega & 61,5 & \\
\hline datumska meja & 60,4 & \\
\hline Galaksija & & \\
\hline
\end{tabular}

Tabela 2: OSNOVNA ŠOLA - 7. razred: skupno 84 pojmov oz. gesel.

\begin{tabular}{|l|l|l|c|}
\hline UČITELJI & UČENCI & \\
\hline POJEM & $\%$ & POJEM & $\%$ \\
\hline zenitno deževje & 68,1 & sisal & 84,3 \\
\hline & & vadi & 76,5 \\
& & Buri & 74,3 \\
\hline & prerijska črnica & 73,5 \\
\hline & Mestici & 71,8 \\
\hline & & Berberi & 67,5 \\
\hline & prerija & 64,7 \\
\hline & & kondenzacija & 62,7 \\
\hline & & Sahel & 60,5 \\
\hline
\end{tabular}


Tatjana Resnik Planinc / Dela 18 • 2002 • 333-347

Tabela 3: OSNOVNA ŠOLA - 8. razred: skupno 74 pojmov oz. gesel

\begin{tabular}{|c|c|c|c|}
\hline \multicolumn{2}{|c|}{ UČITELJI } & \multicolumn{2}{|l|}{ UČENCI } \\
\hline POJEM & $\%$ & POJEM & $\%$ \\
\hline \multirow[t]{14}{*}{1} & & melioracija & 86,6 \\
\hline & & tranzitni promet & 81,9 \\
\hline & & migracijski tok & 80,6 \\
\hline & & hektarski donos & 79,7 \\
\hline & & zakrasevanje & 78,8 \\
\hline & & vodostaj & 78,1 \\
\hline & & prehodna pokrajina & 72,1 \\
\hline & & kot & 68,3 \\
\hline & & $\begin{array}{l}\text { intenzivno/ekstenzivno } \\
\text { kmetijstvo }\end{array}$ & 67,5 \\
\hline & & specializacija & 66,2 \\
\hline & & kvartarna dejavnost & 66,1 \\
\hline & & dinarska slemenitev & 64,7 \\
\hline & & terciarna dejavnost & 64,1 \\
\hline & & $\begin{array}{l}\text { vzdrževano } \\
\text { prebivalstvo }\end{array}$ & 60,5 \\
\hline
\end{tabular}

Tabela 4: SPLOŠNA GIMNAZIJA-1. letnik-349 pojmov oz. gesel.

\begin{tabular}{|l|c|l|c|}
\hline UČITELJI & \multicolumn{2}{l|}{ UČENCI } \\
\hline POJEM & $\%$ & POJEM & $\%$ \\
\hline $\begin{array}{l}\text { teorija demograf. } \\
\text { prehoda }\end{array}$ & 73,1 & megalopolis & 85,2 \\
\hline mezofiti & 61,5 & čok & 81,5 \\
\hline & & mezofiti & 80,4 \\
\hline & & higrofiti & 80,3 \\
\hline & & klimatska kolebanja & 79,5 \\
\hline & & kserofiti & 79,5 \\
\hline & & sinklinalinala & 79,1 \\
\hline & & degradacija prsti & 77,3 \\
\hline & & somestje & 73,5 \\
\hline & & aridna-semiaridna & 70,2 \\
\hline & & območja & 66,0 \\
\hline & & projekcija prebivalstva & 63,9 \\
\hline & & intraconalne prsti & 63,1 \\
\hline & & rendzina & 62,5 \\
\hline & & aconalne prsti & 62,2 \\
\hline & & mestoslužne funkcije & 61,9 \\
\hline & & conalne prsti & 61,6 \\
\hline & & podor & 60,7 \\
\hline & & mestotvorne funkcije & 60,0 \\
\hline & & & \\
\hline & & & \\
\hline & & &
\end{tabular}


Vrednotenje zahtevnejših geografskih učnih vsebin na vseh ravneh izobraževanja

Tabela 5: SPLOŠNA GIMNAZIJA - 2. letnik-57 pojmov oz. gesel.

\begin{tabular}{|c|c|c|c|}
\hline \multicolumn{2}{|c|}{ UČITELJI } & \multicolumn{2}{|l|}{ UČENCI } \\
\hline POJEM & $\%$ & POJEM & $\%$ \\
\hline 1 & & 1 & \\
\hline
\end{tabular}

Tabela 6: SPLOŠNA GIMNAZIJA - 3. letnik-82 pojmov oz. gesel.

\begin{tabular}{|l|c|l|c|}
\hline UČITELJI & UČENCI & \% \\
\hline POJEM & $\%$ & POJEM & 86,6 \\
\hline & & logi & 86,2 \\
\hline & & resave & 84,8 \\
\hline & mezzogiorno & 82,4 \\
\hline & lesostepje & 69,7 \\
\hline & kmetijski trikotnik & 69.2 \\
\hline & sovhozi & 67,6 \\
\hline & kantonalna ureditev & 64,7 \\
\hline & kolhozi & 61,7 \\
\hline & Cambridge fenomen & 60,7 \\
\hline
\end{tabular}

Tabela 7: SPLOŠNA GIMNAZIJA - 4. letnik-86 pojmov oz. gesel.

\begin{tabular}{|l|c|l|c|}
\hline UČITELJI & UČENCI & \\
\hline POJEM & $\%$ & POJEM & $\%$ \\
\hline$l$ & & zatok & 80,3 \\
\hline & & mrtvice & 74,4 \\
\hline
\end{tabular}

Tabela 8: STROKOVNA GIMNAZIJA - 136 pojmov oz. gesel.

\begin{tabular}{|l|c|l|c|}
\hline UČITELJI & UČENCI & \% \\
\hline POJEM & $\mathbf{\%}$ & POJEM & 89,5 \\
\hline konurbacija & 80,0 & antropogena prst & 88,2 \\
\hline $\begin{array}{l}\text { kemijske lastnosti } \\
\text { prsti }\end{array}$ & 60,0 & demografski prehod & 84,9 \\
\hline megalopolis & 60,0 & klasifikacija držav & 84,6 \\
\hline & & slum & 84,4 \\
\hline & & konurbacija & 82,2 \\
\hline & troposfera & 81,7 \\
\hline & položaj SLO glede na kriterije & za določanje razvitosti & 80,4 \\
\hline & & kriteriji za določanje razvitosti & 78,6 \\
\hline & & kemijske lastnosti prsti & 78,5 \\
\hline & & tematska karta & 77,4 \\
\hline & & megalopolis & \\
\hline
\end{tabular}




\begin{tabular}{|c|c|l|c|}
\hline \multirow{3}{*}{} & socialna geografija mesta & 76,8 \\
\hline & & demografsko območje & 76,5 \\
\hline & demografski režim & 75,7 \\
\hline & demografska eksplozija & 73,4 \\
\hline & podzol & 72,6 \\
\hline & $\begin{array}{l}\text { vzroki spreminjanja ekosiste- } \\
\text { mov }\end{array}$ & 71,7 \\
\hline & fizikalne lastnosti prsti & 71,0 \\
\hline
\end{tabular}

Tabela 9: SREDNJE TEHNIČNE IN POKLICNE ŠOLE - 45 pojmov oz. gesel.

\begin{tabular}{|l|c|l|c|}
\hline UČITELJI & UČENCI & $\%$ \\
\hline POJEM & $\%$ & POJEM & 76,1 \\
\hline regija & 84,6 & $\begin{array}{l}\text { gospodarski, politični in kul- } \\
\text { turni tokovi }\end{array}$ & 66,6 \\
\hline & & pomen elementov pokrajine & krizno žarišče \\
\hline
\end{tabular}

\subsection{Drugi del raziskovalnega dela}

V drugem delu raziskave so učitelji odgovarjali na 30 vprašanj o uporabi ter izboru učnih metod in oblik, načrtovanju in ustrezni izvedbi pouka geografije, samoevalvaciji učiteljevega dela itd.

V prvem delu raziskave, v katerem so sodelovali učitelji geografije in učenci in s katero smo ugotavljali stopnjo zahtevnosti geografskih pojmov $\mathrm{v}$ sklopu posameznih, z učnimi načrti predpisanih učnih vsebin, je prišlo med učitelji in učenci do velikega razkoraka $v$ definiranju zahtevnejših pojmov in gesel. Učitelji namreč uvrščajo med zahtevnejše pojme občutno manjše število pojmov kot učenci. Ta razkorak pripisujejo učitelji različnim dejavnikom in vzrokom. Med drugim navajajo, da učenci pojmov niso usvojili tako, kot so mislili učitelji in da je pojmov preveč, da so dijaki preveč obremenjeni z novimi pojmi pri vseh predmetih in da je tisto, kar je za učitelja samoumevno za učence dodatni napor. Razlike pripisujejo drugačnemu nivoju dojemanja in znanja, nezanimanju učencev, premajhnemu utrjevanju snovi, prepovršnemu učenju, premajhnemu predznanju učencev, manjšemu besednemu zakladu in pomanjkanju izkušenj, delovanju učencev po »liniji najmanjšega napora« ter težavam z lastnim vživljanjem v mišljenje otrok, ker gre za razlike v znanju, izkušnjah in interesih. Nadalje učitelji ugotavljajo, da se učenci učijo kampanjsko, da je med učenci in učiteljem premalo komunikacije, da so učenci preobremenjeni, ker so pojmi prezahtevni in prenasičeni, ter da so učitelji prepričani, da je večina osnovnih pojmov že usvojena. Po mnenju nekaterih 
učiteljev je to znanje neutrjeno, ker so učni načrti prezahtevni, učbeniki slabi, pojmi pa slabo razloženi. Učitelji se čutijo obremenjeni z učnimi cilji, ki jih zahteva učni načrt, obenem pa se nekateri zavedajo tudi lastne nesposobnosti ločevanja bistvenega od nebistvenega.

Po mnenju učiteljev so določeni geografski pojmi oziroma gesla zahtevnejši od drugih zaradi njihove abstraktnosti, težje predstavljivosti, ker prehitevajo razvojno stopnjo otrok ali pa zahtevajo sintezo znanja, ki jo otroci še niso sposobni narediti, ker jih je enostavno preveč, ker se ne pojavljajo kontinuirano in jih otroci ne uporabljajo $\mathrm{v}$ vsakodnevnem življenju, ker se $\mathrm{v}$ različnih učbenikih pojavljajo različne definicije, ker so jim tuji in se $\mathrm{z}$ njimi še niso srečali v vsakodnevnem življenju, ker zahtevajo določeno predznanje, ker so slabo razloženi.

Ob vsem povedanem je zanimiva določena mera samokritičnosti, ki so jo učitelji pokazali $\mathrm{v}$ odgovorih na vprašanje o vzrokih zahtevnosti določenih učnih vsebin. Iz grafa 1 je razvidno, da je več kot polovica (56'2 \%) navedla kot glavni vzrok kar učitelje same oziroma njihov način podajanja snovi, pomanjkljivo poznavanje določenih tem, itd., $40 \%$ jih vidi vzrok v pomanjkljivih materialnih pogojih, nekoliko manj pa $\mathrm{v}$ učnem načrtu in izboru učnih oblik in metod. Le 30'5 \% učiteljev išče vzrok v učencih. 13'3 \% anketirancev kot glavni razlog navaja neprivlačnost določenih učnih vsebin, njihovo abstraktnost, preveliko količino informacij, pomanjkljivo predznanje učencev in njihovo nesposobnost logičnega mišljenja.

Graf 1: Vzroki zahtevnosti določenih geografskih učnih vsebin.

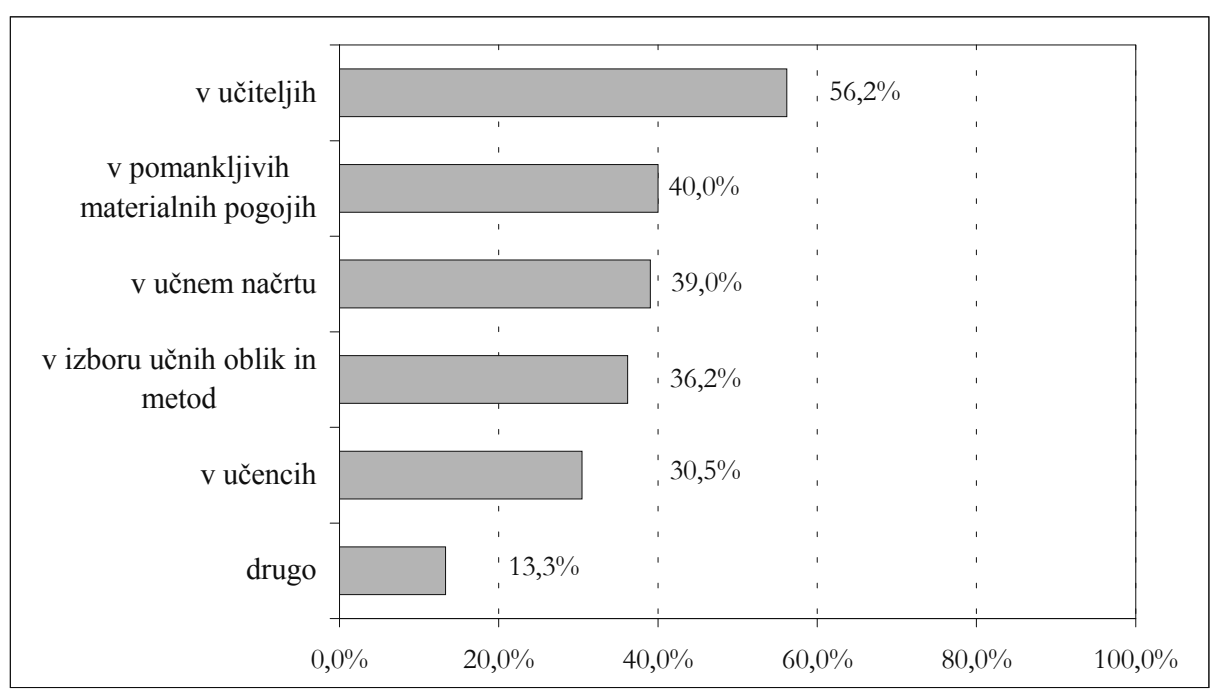


Čeprav učenci pogosto ne razumejo določenih pojmov, so po mnenju $54 ' 7$ \% učiteljev zahtevnejši pojmi oziroma gesla smiselni in potrebni za obravnavo. $21^{\prime} 7 \%$ učiteljev bi te pojme izločilo, 23 '6 \% pa pravi, da je njihova obravnava smiselna, če jih jasno razložimo in praktično pokažemo, če so nujni za realizacijo učnih ciljev ter da je odvisno v kolikšni meri njihovo poznavanje vpliva na razumevanje ostale učne snovi.

Pri tem kar 70'1 \% učiteljev zahtevnejše učne vsebine drugače vrednoti kot manj zahtevne. Pomagajo si z diferenciacijo, se jim bolj posvetijo, vključujejo jih v dodatna vprašanja pri pisnih nalogah, zahtevajo jih le od sposobnejših učencev, namenijo jim več časa za preverjanje, izberejo ustrezne metode za njihovo obravnavo, pri ocenjevanju jih višje vrednotijo, poenostavijo jih.

Probleme, ki nastopijo pri obdelavi zahtevnejših učnih vsebin, rešujejo učitelji z ustreznim izborom učnih oblik in metod (74'7 \%) ali pa jim namenijo več časa $\left(74^{\prime} 7 \%\right)$ in le $7^{\prime} 4 \%$ učiteljev se jim izogne.

$\mathrm{V}$ zadnjem vprašanju smo učitelje prosili, da označijo geografske pojme, katerih vključitev v učni načrt se jim ne zdi potrebna in smiselna za učenčevo razumevanje. Seznam pojmov je vključeval tiste pojme, ki jih je v prvem delu raziskave več kot $40 \%$ učiteljev definiralo kot zahtevne. Anketiranci so obravnavali samo tiste pojme, ki so se nanašali na vrsto šole, v kateri poučujejo oziroma na program po katerem poučujejo.

$\mathrm{V}$ tabelah so po posameznih vrstah šol prikazani samo tisti pojmi oz. gesla, ki bi jih več kot $40 \%$ učiteljev izključilo iz učnega načrta.

Tabele 10 - 14: Vrednotenje smiselnosti prisotnosti posameznih geografskih pojmov na različnih ravneh geografskega izobraževanja.

10.

\begin{tabular}{|l|c|c|}
\hline OSNOVNA ŠOLA (6., 7., 8. razred) & \multicolumn{1}{|l|}{} \\
\hline zahtevnejši pojmi oz. gesla & št. & \% \\
\hline svoboden pretok ljudi, blaga in delovne sile & 19 & 43,1 \\
\hline svetlobno leto & 18 & 40,9 \\
\hline
\end{tabular}

11.

POKLICNA ŠOLA
\begin{tabular}{|l|c|c|}
\hline zahtevnejši pojmi oz. gesla & št. & \% \\
\hline geografska enota & 3 & 75 \\
\hline mednarodna delitev dela & 3 & 75 \\
\hline pretok ljudi in dobrin & 2 & 50 \\
\hline $\begin{array}{l}\text { pomen elementov pokrajine za človeka in } \\
\text { gospodarstvo }\end{array}$ & 2 & 50 \\
\hline
\end{tabular}


12.

\begin{tabular}{|l|c|c|}
\hline \multicolumn{3}{|l|}{ SREDNJE TEHNIČNE ŠOLE } \\
\hline Zahtevnejši pojmi oz. gesla & št. & $\%$ \\
\hline gospodarski, politični in kulturni tokovi & 4 & 80 \\
\hline regija & 3 & 60 \\
\hline družbeno-geografska pestrost & 2 & 40 \\
\hline tipi pokrajin & 2 & 40 \\
\hline naravno-geografska pestrost & 2 & 40 \\
\hline
\end{tabular}

13.

\begin{tabular}{|l|c|c|}
\hline \multicolumn{2}{|l|}{ STROKOVNA GIMNAZIJA } & \multicolumn{2}{l|}{ șt. } & $\%$ \\
\hline zahtevnejši pojmi oz. gesla & 4 & 100 \\
\hline Sial & 4 & 100 \\
\hline Sima & 4 & 100 \\
\hline konurbacija & 3 & 75 \\
\hline laterit & 2 & 50 \\
\hline tropogena prst & 2 & 50 \\
\hline megalopolis & 2 & 50 \\
\hline demografski prehod & 2 & 50 \\
\hline herbicid & & \\
\hline
\end{tabular}

14.

\begin{tabular}{|l|c|c|}
\hline \multicolumn{3}{|l|}{ SPLOŠNA GIMNAZIJA (1., 2., 3., 4. letnik) } \\
\hline zahtevnejši pojmi oz. gesla & št. & \% \\
\hline zatok & 16 & 80 \\
\hline mezofiti & 14 & 70 \\
\hline lesostepje & 14 & 70 \\
\hline čok & 13 & 65 \\
\hline astenosfera & 10 & 50 \\
\hline Mezzogiorno & 9 & 45 \\
\hline zrnavost (tekstura) & 8 & 40 \\
\hline
\end{tabular}

Glede na zgoraj prikazane rezultate lahko ugotovimo, da naj bi velika večina pojmov, ki so sicer tudi po mnenju učitelj zahtevnejši za njihove učence in dijake, ostala v učnih načrtih še naprej. Tu se srečamo z že znanim paradoksom selekcije. V pavšalnih ocenah učnih načrtov se neprestano pojavljajo izrazi kot so preobsežnost, prezahtevnost, neprimernost, neustreznost, ko pa želimo ugotoviti, kaj lahko stroka pogreša $\mathrm{v}$ geografskih kurikulumih in to jasno definirati, postane naenkrat vse pomembno. Učitelji v svojih izjavah pogosto niso dosledni, saj v odgovorih nemalokrat zanikajo sami sebe oziroma tisto, kar so trdili nekaj odgovorov prej. 
Na univerzitetnem nivoju so študenti v sklopu posameznih predmetov ravno tako izpostavili težje študijske vsebine, vendar bomo v nadaljevanju na kratko prestavili le njihove odgovore na vprašanje, čemu pripisujejo svoje težave $\mathrm{z}$ določenimi vsebinami, pojmi in gesli.

Svoje težave z določenimi vsebinami, pojmi in gesli pri posameznih predmetih pripisujejo študenti predvsem:

- njim popolnoma novim vsebinam, ki jih zaradi hitrosti podajanja ne morejo usvojiti,

- lastnim problemom z logičnim mišljenjem ter povezovanjem,

- količini podatkov, obsežni snovi,

- slabemu predznanju iz srednje šole,

- pomanjkanju lastne zavzetosti in sprotnega dela,

- neustrezni ali prezahtevni (tuji) literaturi, pomanjkanju gradiva,

- neustrezni razlagi predavateljev,

- lastnemu manjšemu zanimanju za nekatere teme,

- premajhni količini praktičnega dela,

- monotonosti snovi,

- nepotrebni faktografiji,

- koncentraciji izpitov v kratkem izpitnem obdobju, posledica česar je površno učenje,

- pomanjkanju komunikacije in sodelovanja med študenti in predavatelji,

- pomanjkanju motivacije,

- premajhnemu številu ur predavanj,

- zahtevnosti vsebin,

- učenju na pamet,

- lastni neorganiziranosti in lenobi,

- lastni nenadarjenosti za matematiko in fiziko,

- lastnemu nedelu in nevestnosti,

- previsokim pričakovanjem profesorjev,

- pomanjkanju časa,

- nezanimivim vsebinam,

- nerednemu obiskovanju predavanj,

- premajhnemu poudarku na težjih vsebinah,

- premajhni nazornosti,

- sistemu ocenjevanja,

- nesistematičnosti,

- pomanjkanju časa za poglabljanje znanja,

- prezaposlenosti predavateljev,

- abstraktnosti snovi,

- kampanjskemu učenju,

- nedostopnosti določene literature, 
- lastnim težavam z memoriranjem,

- pomanjkanju zanimanja,

- prevelikemu deležu teoretiziranja,

- pomanjkanju dialogov med pedagoškim kadrom in študenti,

- neustreznemu času predavanj (zgodnja jutranja ura).

Po mnenju univerzitetnih pedagoških delavcev pa povzroča študentom največ težav:

- povezovanje različnih pokrajinotvornih dejavnikov,

- opredeljevanje bistvenih pokrajinotvornih dejavnikov,

- opredeljevanje relevantnih elementov, pojavov, primerov za interpretacijo regionalnih struktur,

- interpretacija (abstraktnih) modelov.

Analiza odgovorov univerzitetnih pedagoških delavcev kaže, da se v vrednotenju zahtevnejših študijskih vsebin, predvsem pa v njihovem številu, občutno razlikujejo od študentov. Vzrokov je verjetno več in segajo od osebnega nezaznavanja problemov, ki jih imajo študenti z določenimi vsebinami do nezanimanja za povratne odzive $\mathrm{z}$ njihove strani. Zavedati bi se morali, da bomo pedagoški delavci in študenti le s skupnimi močmi, zaupanjem in konstruktivno izmenjavo mnenj dosegli optimalen, obojestransko zadovoljujoč študij geografije.

\section{ZAKLJUČEK}

Rezultati raziskav so pokazali, da:

1. izkazuje pouk geografije večje število zahtevnejših geografskih učnih vsebin,

2. izkazujejo zahtevnejša mesta $\mathrm{v}$ geografskih učnih vsebinah $\mathrm{v}$ osnovni in srednji šoli ter na fakulteti delno podobnost in sovpadanje,

3. se učenci, dijaki in študenti ter njihovi učitelji in profesorji $\mathrm{v}$ definiranju zahtevnih geografskih učnih vsebin razhajajo,

4. boljše razumevanje in poznavanje težjih učnih vsebin ter primernih metod za njihovo podajanje omogoča učitelju lažje delo ter daje mnogo boljše učne rezultate,

5. se učitelji nehote lotevajo težjih učnih vsebin z manjšim veseljem in navdušenjem,

6. se geografske vsebine iz matematične in fizične geografije niso izkazale za zahtevnejše od vsebin iz družbene in regionalne geografije,

7. je razumevanje geografskih vsebin, ki se nanašajo na tuje in oddaljeno zahtevnejše od domačega in bližnjega, 
8. z vidika zahtevnejših učnih vsebin delo učiteljev geografije redko temelji na povezavi z drugimi šolskimi predmeti,

9. so zahtevnejše geografske učne vsebine neenakomerno razporejene v šolski vertikali,

10. na reševanje problemov lahko odločilno vpliva strokovna usposobljenost, osebnost ter izkušnje učitelja.

Nujen pogoj za doseganje zahtevnejših vzgojnoizobraževalnih ciljev je obvladovanje različnih pristopov, oblik, metod in tehnik dela. Za povečanje njihove raznolikosti je potrebno dati večji poudarek ustrezni strokovni in predvsem specialno-didaktični pripravi ter pomoči učiteljem.

Vzgojno-izobraževalni cilji pouka geografije so oblikovani tako, da zahtevajo za svojo realizacijo uporabo sodobnih inovativnih metod. Številni cilji sodobnega pouka so $\mathrm{v}$ primerjavi s prejšnjimi učnimi načrti oblikovani tako, da zahtevajo in usmerjajo učence $\mathrm{k}$ samostojnemu in kooperativnemu učenju, $\mathrm{k}$ veliki aktivnosti pri iskanju ustreznih rešitev, argumentiranju, teamskemu in individualnemu delu. Tako postavljeni cilji sodobnega pouka so enaki tudi ciljem sodobnega geografskega pouka. Za šolsko delo imamo na razpolago vedno več kvalitetnega učnega gradiva in učitelj bo lahko selektivno odbiral kaj in kako bo uporabil pri svojem delu, vendar je nujno, da dodiplomsko izobraževanje bodoče učitelje usposobi za tovrstne naloge. (Kolenc-Kolnik, 1996, 25)

Strinjamo se z J. Kunaverjem, ki pravi, da je permanentno izobraževanje na področju geografije razmeroma razvito, a povsem neusklajeno med inštitucijami in posamezniki. Težiti moramo $\mathrm{k}$ temu, da ne bi nikomur, ki je strokovno usposobljen, kratili pravice do lastnega dela in uveljavljanja, obenem pa bi se morali ogibati podvajanju in nezdravi konkurenci. (Kunaver, 1996, 7-8)

Čeprav so izobraževalni cilji jasno definirani, nam ne povedo, kako naj jih dosežemo. Na začetku bi bilo potrebno ugotoviti močna in šibka mesta posameznika za njegovo profesionalno rast. Pri tem bi se morali zavedati našega končnega cilja: želimo, da bi bil ob zaključku študija učitelj geografije usposobljen za razumevanje znanja, konceptov in spretnosti, ki jih zahteva predmet geografija ter da bi poznal njen položaj v šolskih kurikulumih. Študentom ne zadostuje le poznavanje informacij, ki so jih pridobili iz različnih virov. Usposobiti bi se morali za soočanje z vsakodnevnimi situacijami in za njihovo razumevanje, obenem pa bi morali biti sposobni oblikovanja lastnega mnenja in sodb o geografskem izobraževanju. To bodo dosegli veliko laže, če bodo imeli v času študija možnost razpravljati o svojih izkušnjah z drugimi in se seznaniti z različnimi stališči. Ob istem razponu dela bodo različni študenti spoznali različne stvari, ki bodo odvisne od njihovega zanimanja za določen vidik študija, znanja in izkušenj, ki jih prinašajo s sabo v določeno aktivnost in količino časa, ki ga bodo porabili zanjo. Zavedati pa se moramo, da sama 
usposobljenost $\mathrm{v}$ stroki še ne zagotavlja oziroma ne usposablja za poučevanje geografije.

Učitelji geografije bi morali biti usposobljeni:

- za izvajanje koherentnega pouka $\mathrm{v}$ skladu z učnim načrtom in zahtevami šole,

- za zagotavljanje kontinuitete in razvoja znotraj razreda in med razredi ter med šolskimi predmeti,

- za postavljanje primerno zahtevnih pričakovanj do učencev,

- za uporabo različnih učnih strategij, ki bodo ustrezale psihofizičnim sposobnostim učencev,

- za predstavljanje vsebine predmeta $\mathrm{v}$ jasnem jeziku in na stimulativen način,

- za razvijanje komunikacijskih sposobnosti učencev,

- za selekcijo in uporabo ustreznih virov, vključno z informacijsko tehnologijo.

Nadaljnji profesionalni razvoj učitelja geografije bi moral vključevati:

- razumevanje šole kot institucije in njenega položaja znotraj skupnosti,

- poznavanje obveznosti učitelja,

- sposobnost razvijanja ustvarjalnih delovnih odnosov s kolegi in starši ter razvijanje lastnih komunikacijskih sposobnosti,

- zavedanje individualnih razlik, vključno s socialno, psihološko razvojno in kulturno razsežnostjo,

- sposobnost prepoznavanja različnosti talentov vključno s prepoznavanjem nadarjenih otrok,

- sposobnost prepoznavanja posebnih izobraževalnih potreb in učnih težav otrok,

- samokritičen pristop $\mathrm{k}$ diagnosticiranju in vrednotenju učenčevega učenja vključno s spoznavanjem vpliva tega učenja na učiteljeva pričakovanja.

Znotraj stroke je za razvoj šolske geografije zelo pomembno, kakšen je sistem izobraževanja bodočih učiteljev, kakšen je položaj pedagoške usmeritve na posameznih oddelkih in kako gledajo nepedagoški geografi na pedagoško poslanstvo geografije, kakšen je sistem permanentnega izobraževanja in kako je šolska geografija organizirana $\mathrm{v}$ osrednji stanovski organizaciji. (Kunaver, 1996, 8)

Zavedamo se, da za posodobitev in prenovitev pouka geografije $\mathrm{v}$ skladu $\mathrm{z}$ družbenimi potrebami ter cilji in načeli kurikularne prenove ne zadostujejo samo potrjeni učni načrti, izdelani standardi in katalogi znanj, ampak da se prava prenova začenja šele $\mathrm{v}$ šoli, znotraj kolektivov in na individualni strokovni ravni vsakega posameznika. Te spremembe pa je najteže doseči, ker so vezane na spreminjanje ustaljenih vzorcev delovanja učiteljev in na tradicionalno razumevanje komunikacije pri pouku $\mathrm{v}$ smislu posredovanja znanja in 
informacij ter na njihovo ustrezno preverjanje. Novi učni načrti predvidevajo mnogo večjo stopnjo medpredmetnih povezav, vključevanje raznolikih pristopov, oblik in metod dela, večjo kakovost pridobljenega znanja, ki naj bi ga učenci ne le usvajali, ampak tudi ustvarjalno uporabljali v novih situacijah.

$\mathrm{V}$ prihodnosti bi bilo smiselno nadaljevati z raziskovalnim delom na področju šolske geografije v smislu:

- izbora in usklajevanja zahtevnosti učnih vsebin z zahtevami stroke ter psihofizičnim razvojem in sposobnostmi otrok in mladostnikov,

- strokovno neoporečne selekcije števila pojmov in učnih vsebin v vertikali geografskega izobraževanja,

- vsaj delnega poenotenja števila in zahtevnosti učnih vsebin v vertikali geografskega izobraževanja,

- razvijanja medpredmetnega sodelovanja,

- natančne določitve pragov zahtevnosti v vertikali geografskega izobraževanja,

- usposabljanja učiteljev za izbor in uporabo ustreznih učnih oblik in metod ter uporabo različnih učnih pripomočkov, predvsem pa za spremljanje in uporabo novosti na področju izobraževanja,

- stalnega strokovnega spopolnjevanja učiteljev geografije.

Le s stalnim raziskovalnim delom, težnjami $\mathrm{k}$ izboljšanju obstoječega stanja, iskanjem novih poti in oblik dela, stalnim preverjanjem in vrednotenjem bomo v šolski geografiji dosegali zastavljene cilje in osmislili našo željo po kakovostnem geografskem izobraževanju.

\section{Viri in literatura:}

Kolenc-Kolnik, K., 1996: Mednarodno razumevanje in sodelovanje v luči geografske vzgoje in izobrazbe: na primeru slovensko-italijanskega in slovensko-madžarskega obmejnega prostora. Doktorska disertacija. 156 str.

Kunaver, J., 1996: Didaktika geografije včeraj, danes in jutri. Dela 6. Oddelek za geografijo, Filozofska fakulteta v Ljubljani, str. $40-51$.

Resnik Planinc, T., 2001: Zahtevnejše geografske učne vsebine kot izobraževalni problem. Doktorska disertacija. 248 str. 
Vrednotenje zahtevnejših geografskih učnih vsebin na vseh ravneh izobraževanja

\section{EVALUATION OF MORE DEMANDING GEOGRAPHICAL CONTENTS REGARDING ALL EDUCATIONAL LEVELS}

\section{Summary}

The article deals with a didactical problem of transfer and understanding of more demanding geographical contents, which are included into geographical educational vertical. Further improvement of geography teaching and assurance of high quality syllabus on every level of geographical education require a defining of more demanding geographical contents and reasons for their difficulty, argumentation of their incorporation into syllabuses and assessment of ways and methods for dealing with them and their adoption. Problem of more demanding geographical contents also presents topical methodological issue in international frames.

Apart from the awareness of the importance of geographical education, geography science has to tend towards the most appropriate representation of geographical contents in the whole school vertical because many of them are necessary for educational reasons. Regarding all these the understanding and mastering of geographical contents and didactic methods is also necessary for future geography teachers.

The article offers the origins for better organisation of contents in the vertical of geographical education and the origins for better education of future geography teachers. The results of research work offer the possibility for further finding of analogy and differences on international level.

The analysis of the transfer of scientifically demanding geographical contents into school syllabuses along with the defining of demanding geographical contents, methods and forms of their teaching, the defining of interdisciplinary approach, complexity and international comparison of geographical education for school needs, this article sets the origins or frames for further development of didactic of geography and geographical education itself.

The author also researches the state of primary and secondary school geography regarding the educational work of geography teachers. She tries to evaluate teacher's knowledge of successful geography teaching and his or her familiarity with teaching of certain geographical contents. According to the results she ranks the components, which are important for a good planning of geography teaching, and examines the teachers' awareness of the pedagogical and psychological teaching views.

The article deals with the results of teacher's self-evaluation considering his or her own work. According to the results of the research the author finally discusses the possibilities of development of a new quality of geographical education. 